\title{
INFLUÊNCIA DE QUEIMADAS NA REDUÇÃO DA INCIDÊNCIA DE RADIAÇÃO SOLAR OBSERVADA POR ESTAÇÕES DO PROJETO SONDA NO TERRITÓRIO BRASILEIRO
}

\author{
Ana Luiza Ferreira de Almeida ${ }^{1}$ (Universidade Brás Cubas, Bolsista PIBIC/CNPq) \\ Fernando Ramos Martins ${ }^{2}$ (CCST/INPE - Coorientador) \\ Enio Bueno Pereira ${ }^{3}$ (CCST/INPE - Orientador)
}

\section{RESUMO}

Este trabalho, iniciado em agosto de 2010, tem como objetivo estudar a relação entre as queimadas ocorridas no Brasil e a quantidade de radiação solar incidente na superfície terrestre. Estudos anteriores mostram que os aerossóis lançados à atmosfera em eventos de queimada atenuam a radiação solar durante seu percurso na atmosfera, causando assim uma diferença no balanço radiativo terrestre. Para o desenvolvimento deste estudo, utilizou-se dados de irradiação solar coletados nas estações solarimétricas da rede SONDA (Sistema de Organização Nacional de Dados Ambientais), e dados do de focos de queimada disponibilizados pelo DSA/CPTEC/INPE (Divisão de Satélites e Sistemas Ambientais) que efetua operacionalmente o monitoramento por imagens de satélites. Foram selecionados dias de céu claro por meio de análise dos dados de irradiação solar, global, difusa e direta, coletados nas estações localizadas em Brasília, Caicó, Cuiabá, Campo Grande, Florianópolis, Ourinhos, Palmas, Petrolina, Rolim de Moura, São Martinho da Serra estão sendo utilizados. Estas estações foram escolhidas em razão de sua localização na região de ocorrência de queimadas ou estão no percurso do transporte atmosférico dos aerossóis lançados à atmosfera. Os dados de irradiação solar aapresentam uma resolução temporal de 1 minuto, permitindo avaliar de forma simples a ocorrência de séu claro. Os dados de número de focos de queimada disponíveis fornecem a média diária de focos de incêndio em quadrículas para o período entre os anos de 1993 a 2010 contendo os pontos exatos com latitude e longitude dos locais imageados pelo satélite NOAA. Scripts em MATLAB e EXCEL foram desenvolvidos para calcular o total de irradiação solar nos dias de céu claro e para armazenar os valores da quantidade de focos de queimada para os períodos referentes ao dias de céu claro selecionados. O próximo passo é avaliar por meio de análises estatísticas se a presença de queimadas nas proximidades do local da estação provoca uma redução nos valores de irradiação solar global observada na superfície acompanhada apor um incremento da irradiação solar difusa. Comparação entre valores coletados durante a estação seca e úmida será realizada para determinar a influência dos aerossóis.

\footnotetext{
${ }^{1}$ Estudante do curso de Engenharia Ambiental. Bolsista vinculada ao grupo de Energias Renováveis e Clima do CCST/INPE.

E-mail: analuizafal@gmail.com

${ }^{2}$ Pesquisador do Centro de Ciência do Sistema Terrestre - CCST/INPE - MCT

E-mail: fernando.martins@inpe.br

${ }^{3}$ Pesquisador do Centro de Ciência do Sistema Terrestre - CCST/INPE - MCT

E-mail: enio.pereira@inpe.br
} 